\title{
The essential enterprise: the critical role of accreditation in the 21st century
}

\author{
Jason R. Frank ${ }^{1,2^{*}}$, Sarah Taber ${ }^{1}$, Marta van Zanten ${ }^{3}$, Fedde Scheele ${ }^{4,5,6}$, Danielle Blouin ${ }^{7}$ and on behalf of the \\ International Health Professions Accreditation Outcomes Consortium
}

Health professions education (HPE) is undergoing rapid change to a competency-based world, and accreditation change is part of that story [1-4]. Despite over 100 years of scientific, instructional, and biomedical innovation, health professions education continues to face criticism. Deficits and variations in graduate competence, patient harm, and preparedness for modern health care are considered major challenges for current designs for HPE [5, 6]. Can accreditation help to address these issues?

Accreditation is commonly viewed as an essential component of an effective health professions education (HPE) system, valued both as a lever for quality assurance as well as for continuous quality improvement. However, for such an essential enterprise, the body of literature on HPE accreditation is small. Accreditation systems exist worldwide in a wide variety of forms. Do we all agree on what we mean by "accreditation"? What are the essential components of an accreditation system? What works best for a given context? What are the emerging issues in contemporary education? What are best and "next" practices? We have only the work of a few pioneering scholars to inform these questions, and no global consensus on which to advance our thinking.

Enter an accreditation community of practice, the International Health Professions Accreditation Outcomes Consortium (IHPAOC). We founded this organization in 2012 to advance the practice of HPE accreditation.

To date, this group has organized two world summits on HPE accreditation, one in 2013 in conjunction with the International Conference on Residency Education

\footnotetext{
* Correspondence: jrank@royalcollege.ca

'Office of Specialty Education, Royal College of Physicians and Surgeons of Canada, Ottawa, Canada

${ }^{2}$ Department of Emergency Medicine, University of Ottawa, Ottawa, Canada Full list of author information is available at the end of the article
}

(ICRE) in Calgary, Canada, and the second in 2018 in conjunction with the Association for Medical Education in Europe (AMEE) conference in Basel, Switzerland. Both summits used an iterative group process to identify themes related to the current state of and future directions for HPE accreditation.

At its first world summit in 2013, IHPAOC members from around the world, including Canada, the United States, Australia, Europe and China, began a collaborative process of discussion and consensus-building to identify priority topics and build a research agenda. Working groups were formed to further elaborate on the identified topics and each group produced a paper. BMC Medical Education was chosen as vehicle to widely disseminate the IHPOAC findings in an open access format. This is the resulting accreditation paper series.

Each paper makes a primary contribution to the literature on accreditation. The first paper in this series by Frank et al. presents a new definition of accreditation, examines its purpose and return on investment, and defines 10 fundamental and recurring elements of accreditation systems commonly found in HPE. The second paper by Taber et al. provides a framework for operational design decisions for accreditation systems. The third paper, by Bandiera et al., explores the need for accreditation systems to shift their focus from processes to outcomes. The fourth paper in the series by Akdemir et al. examines the role of continuous quality improvement and develops a core values framework for accreditation. The last paper, written by Philibert et al., describes four priorities to enhance the societal responsiveness of HPE, and identifies approaches at the system, institution, program and individual levels using accreditation as a lever for change.

Many thanks to all the participants in the IHPOAC community for all their contributions. It is our hope that

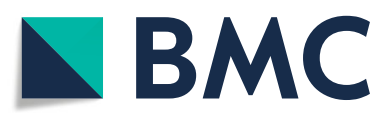

(c) The Author(s). 2020 Open Access This article is licensed under a Creative Commons Attribution 4.0 International License, which permits use, sharing, adaptation, distribution and reproduction in any medium or format, as long as you give appropriate credit to the original author(s) and the source, provide a link to the Creative Commons licence, and indicate if changes were made. The images or other third party material in this article are included in the article's Creative Commons licence, unless indicated otherwise in a credit line to the material. If material is not included in the article's Creative Commons licence and your intended use is not permitted by statutory regulation or exceeds the permitted use, you will need to obtain permission directly from the copyright holder. To view a copy of this licence, visit http://creativecommons.org/licenses/by/4.0/ The Creative Commons Public Domain Dedication waiver (http://creativecommons.org/publicdomain/zero/1.0/) applies to the data made available in this article, unless otherwise stated in a credit line to the data. 
this supplement provides a valuable contribution to the accreditation enterprise. Ultimately, the consortium's goal is to continue to build a body of scholarship connecting good practice in accreditation and impact on health systems and health outcomes.

\section{Abbreviations}

AMEE: Association for Medical Education in Europe; HPE: Health professions education; ICRE: International Conference on Residency Education; IHPAOC: International Health Professions Accreditation Outcomes Consortium

\section{Acknowledgements}

The authors would like to thank the members of the International Health Professions Accreditation Outcomes Consortium, and everyone who reviewed and provided feedback to this project.

\section{About this supplement}

This article has been published as part of BMC Medical Education Volume 20 Supplement 1, 2020: Current themes and challenges facing HPE accreditation in the 21 st century. The full contents of the supplement are available online at https://bmcmedicaleducation.biomedcentral.com/articles/ supplements/volume-20-supplement-1.

\section{Authors' contributions}

JF contributed the main writing and organization of the editorial. ST, MVZ, FS, and DB provided input on the writing and organization. The authors read and approved the final manuscript.

\section{Authors' information}

JRF is Director, Specialty Education, Strategy and Standards in the Office of Specialty Education at the Royal College of Physicians and Surgeons of Canada, and Director of Educational Research and Development in the Department of Emergency Medicine, University of Ottawa. An Associate Professor at the University of Ottawa, Faculty of Medicine, he is crossappointed to the Faculty of Education, University of Ottawa, and the Department of Graduate Studies, Ontario Institute for Studies in Education. ST is the Associate Director of Education Strategy and Accreditation at the Royal College of Physicians and Surgeons of Canada. She holds a master's degree in Health Administration.

MVZ is a Research Scientist for FAIMER and is involved in various research projects related to international medical graduate issues, including accreditation processes of international medical schools, impact of accreditation on student outcomes, doctor-patient relationships, and crosscultural communication skills. Dr. van Zanten holds a B.A. from the University of Waterloo, Ontario, Canada. She also holds an M.Ed. and a Ph. D in Health Studies from Temple University in Philadelphia, Pennsylvania.

FS has worked as a gynecologist and dean at the OLVG teaching hospital in Amsterdam, the Netherlands. He is also a professor in Health Systems Innovation and Education at the VU University Amsterdam and the Athena Institute for Transdisciplinary Research. FS is the national project leader of the curriculum design for postgraduate training in obstetrics and gynecology, and is currently leading the national reform project for accreditation of residency training and medical practice as chairman of the Legislative College for Accreditation of Residency Training in the Netherlands, where he is closely involved in the regulation of training. FS is the president of the board of the Netherlands Association for Medical Education. He also holds positions in several national and international committees and projects in postgraduate training reform. DB is a Professor in the Faculty of Health Sciences, and holds a crossappointment in the Faculty of Education at Queen's University. She completed a Family Medicine/Emergency Medicine residency from the College of Family Physicians of Canada at Queen's University, and an Emergency Medicine residency from the Royal College of Physicians and Surgeons of Canada at McGill University. She also completed a Master of Health Professions Education degree, a PhD in Curriculum and Instruction as well as a Certificate in Educational Research Methodology, all from the University of Illinois at Chicago.

\section{Funding}

No funding was obtained for this study.

Availability of data and materials

Not applicable.

Ethics approval and consent to participate

Not applicable.

\section{Consent for publication}

Not applicable.

\section{Competing interests}

The authors declare that they have no competing interests.

\section{Author details}

'Office of Specialty Education, Royal College of Physicians and Surgeons of Canada, Ottawa, Canada. ${ }^{2}$ Department of Emergency Medicine, University of Ottawa, Ottawa, Canada. ${ }^{3}$ Foundation for Advancement of International Medical Education and Research, Philadelphia, PA, USA. ${ }^{4}$ OLVG Teaching Hospital, Amsterdam, The Netherlands. ${ }^{5}$ VU Medical Center, School of Medical Sciences, Amsterdam, The Netherlands. ${ }^{6}$ Athena Institute for Transdisciplinary Research, Amsterdam, The Netherlands. 'Department of Emergency Medicine, Queen's University, Kingston, Canada.

Published: 28 September 2020

\section{References}

1. World Health Organization. Transforming and scaling up health professional education and training: policy brief $\mathrm{n}$ accreditation of institutions for health professional education. Geneva: WHO; 2013

2. Frank JR, et al. Competence-based medical education: theory to practice. Med Teach. 2010;32:638-45.

3. Nasca T, Philibert I, Brigham T, Flynn T. The next GME accreditation system—rationale and benefits. N Engl J Med. 2012;366(11):1051-6.

4. National Academies of Sciences, Engineering, and Medicine; Health and Medicine Division; Board on Global Health; Global Forum on Innovation in Health Professional Education. Exploring the role of accreditation in enhancing quality and innovation in health professions education: proceedings of a workshop. Washington (DC): National Academies Press; 2016. Available: https://www.nap.edu/download/23636. Accessed 20 Nov 2019.

5. Frenk J, et al. Heath professionals for a new century: transforming education to strengthen heath systems in an interdependent world. Lancet. 2010; 376(9756):1923-58.

6. Asch DA, et al. How do you deliver a good obstetrician? Outcome based evaluation of medical education. Acad Med. 2014;89(1):24-6.

\section{Publisher's Note}

Springer Nature remains neutral with regard to jurisdictional claims in published maps and institutional affiliations.

Ready to submit your research? Choose BMC and benefit from:

- fast, convenient online submission

- thorough peer review by experienced researchers in your field

- rapid publication on acceptance

- support for research data, including large and complex data types

- gold Open Access which fosters wider collaboration and increased citations

- maximum visibility for your research: over $100 \mathrm{M}$ website views per year

At BMC, research is always in progress.

Learn more biomedcentral.com/submission 